\title{
COVID-19: UNA MIRADA BÁSICA
}

Desde que a fines de diciembre de 2019, comenzaron a sonar alarmas desde el oriente específicamente China-Wuhan, en donde un médico oftalmólogo informa casos similares a la presentación clínica del SARS, el Dr. Li Wenliang, a quién brindo mis respetos, ya que falleció después de contraer el virus mientras trataba a pacientes en Wuhan; y que fuera desacreditado por el poder representado en la policía quienes lo acusaron de que "dejara de hacer comentarios falsos" y fue investigado por "propagar rumores".

Un pensamiento no dejo de estar presente en mi diario quehacer ¿Por qué los niños y adolescentes de hasta 14 años, NO están afectados en forma grave, o NO presentan alta tasa de mortalidad? Y sólo una y otra vez la Histología Básica me respondía: el TIMO Y LA MÉDULA ÓSEA, órganos linfoides primarios, en los cuales ocurren los primeros pasos de la diferenciación de los linfocitos T (Timo) y los linfocitos B (Médula Ósea). Los linfocitos B se diferencian en plasmocitos que producen anticuerpos (inmunidad humoral específica) y los linfocitos T se diferencian en: linfocitos T citotóxicos CD8 (+) que reconocen y destruyen a las células infectadas por virus entre otros agentes patógenos y las células tumorales, o en linfocitos T reguladores CD4 (+) que influencian sobre otras células del sistema inmunitario. Los linfocitos $T$ son los efectores de la inmunidad celular específica. Una de las características del sistema inmunitario o sistema linfático adquirido, es su memoria en la forma (específica) circulante que se activan al contacto con su molécula y se multiplican con rapidez.

En otras enfermedades virales como la linfadenitis tipo I, asociada a infección por el virus de la inmunodeficiencia humana $(\mathrm{VIH})$, se expresan cambios histoarquitecturales y citológicos que permiten un diagnóstico de compatibilidad: 1) hiperplasia folicular reactiva, 2) disminución o ausencia del manto linfocitario, 3) linfocitos intrafoliculares (lisis folicular), 4) grados variables de plasmocitosis y proliferación vascular interfolicular y 5) numerosos neutrófilos en sinusoides subcapsulares. Observándose, en la ultraestructura ocasionales partículas virales en células intrafoliculares, y los estudios inmunofenotípicos revelan una disminución marcada de linfocitos-T ayudantes o CD4 intra y extrafoliculares.

Estoy hablando del motivo, y no de las características del agente patógeno, o de las consecuencias nefastas que todos conocemos que ocurren en adultos jóvenes (caso de España con la muerte de un paciente de 21 años COVID-19 positivo y sustrato de enfermedad subyacente) y de la alta tasa de morbilidad-mortalidad en adultos mayores. La respuesta vuelve desde la Histología Básica: el TIMO involuciona a partir de +/- los 14 años, y la MÉDULA ÓSEA experimenta con el envejecimiento normal del humano, una disminución en su parénquima productor de serie blanca, como roja, casi diríamos like-hipoplásica, que impide en ellos una respuesta rápida del agotado sistema inmune primario fisiológico; permitiendo un accionar libre del agente agresor COVID-19, con alteraciones de la homeostasis y las lógicas consecuencias clínico-patológicas en pulmón SDRA (Síndrome de Dificultad Respiratoria Aguda), falla multiorgánica y finalmente el óbito.

En mayo 2020, la Dra. M. Cohen alerta "la presencia de una respuesta al coronavirus en niños afectados representada por un Síndrome Inflamatorio Multisistémico, desarrollando una hiper-respuesta, conocida como Tormenta de Citoquinas", similar a la enfermedad de Kawasaki, ocurriendo en niños sanos que mueren o son afectados como consecuencia de su propia inmunidad.

Solamente rescatar desde esta postura, que nada es de descartar, nada está totalmente conocido, y que desde la Histología Básica como desde la Histofisiología, muchas de las respuestas pueden ser dadas. 